\title{
Gender differences in workplace choices under crisis conditions
}

\author{
Lilia Dominguez V. and Flor Brown G.
}

ABSTRACT

Working from home is an option that differs from other forms of employment. This type of employment is driven not only by globalization and outsourcing, but also by unequal gender relationships within the home. Two multi-logistic regressions were used to determine how the distribution of in-home working arrangements differs by sex and by male/female age range, level of education, marital status and degree of urbanization of the place of residence. The results suggest that these characteristics have a differential influence on men's and women's employment decisions. The results also indicate that the crisis had a strong impact on the employment levels of home-based workers, especially male homeworkers, at the same time that it boosted employment in the services sector. National Autonomous University of Mexico (UNAM).1dv@unam.mx

Flor Brown G. is a postgraduate researcher and professor with the School of Economics of the National Autonomous University of Mexico (UNAM). brown@unam.mx 


\section{I}

\section{Introduction}

The informal economy accounts for $48.5 \%$ of total employment in Latin America (Tokman, 2008). It includes workers who do not have of the social security coverage, training, unemployment insurance, health-care insurance or pensions provided for in labour laws and who are therefore in a highly vulnerable position. This segment of the labour market is dynamic and heterogeneous. It encompasses independent workers employed in subsistence activities, domestic workers, homeworkers, wage earners and independent workers employed in small businesses and workers in formal-sector companies who are not entitled to benefits (ILO, 2005). The size of this sector is worrisome, but an additional cause of concern is the fact that, as a result of the globalization process, new forms of recruitment are gaining in importance at the same time that governments are de-regulating labour markets in order to increase the flexibility of employment arrangements and facilitate outsourcing to small informal firms or home-based workers. As a result, although the informal sector grew by only $1.7 \%$ between 1990 and 2008, forms of employment in the region in which wage levels are substandard or unpredictable rose from $11 \%$ to $15.1 \%$ (Tokman, 2008).

The Mexican economy is no exception. Estimates vary to some extent, but they all indicate that informal employment makes up a large proportion of the economy. According to Tokman (2008), informal-sector employment accounted for $43.7 \%$ of total employment, and forms of employment providing substandard or unpredictable wages accounted for $14.8 \%$ in 2008. Cardero and Espinosa (2013) estimate that informal employment accounted for $64 \%$ of the total in 2009, given the number of people who lack access to employment-based welfare and health-care programmes.

Part of the context for this situation is provided by the neoliberal structural reforms that were introduced in response to the 1982 external debt crisis. These reforms brought about a change in the driving forces behind the economy and ushered in greater stability in

We are grateful to our colleagues, Jenny Cooper and Julio López, for the support that they provided throughout the preparation of this study and to our anonymous referees for their insightful observations, which enabled us to improve this paper. We also owe a debt of gratitude to the Technological Innovation and Research Projects Support Programme of UNAM for the funding provided for Project IN306911-3. some macroeconomic indicators, such as the external public debt, the public deficit and inflation. Nonetheless, production and employment indicators have fallen short of expectations (Ocampo and Ros, 2011). One of the reasons is that economic growth has been fairly moderate compared to the growth rates marked up by the emerging economies of Asia and even those of Latin America. Between 1988 and 1994, the gross domestic product (GDP) climbed by 3.4\%; between 1994 and 2000 (the period during which the country was involved in the North American Free Trade Association (NAFTA), which coincided with an economic boom in the United States, GDP rose by $3.6 \%$, and it edged up by just $2.2 \%$ in 2001-2011.

Even worse, the new pattern of export-led growth has not generated sufficient labour demand to meet the needs of a growing population, since demand has risen fairly slowly in the past 25 years, with average growth rates of $2.7 \%$ for $1988-1993,2.2 \%$ for $1995-2000$, and $1.7 \%$ from 2001 to 2011 . Meanwhile, the open unemployment rate (which does not provide information on underemployment) climbed from $2.2 \%$ to $5.2 \%$ in 2001-2011.

At the same time that an increasing imbalance between a growing labour force and shrinking labour demand has been taking shape, more and more women are becoming involved in the production and distribution of merchandise (De Oliveira and Eternod, 2000; Rendón and Salas, 2000; García, 2001). Women's labour participation rate began to rise in the 1980s, and this increase has spread to all age groups and martial status categories. While a variety of social, cultural and demographic factors account for this shift, the decline in real wages since the 1982 crisis has made it necessary for more and more women to enter the workforce during a time of economic instability in which access to unemployment insurance and universal benefit coverage is often unavailable. The shifts occurring in the labour market have had an impact on both sexes, but women undeniably make up a majority in the categories of vulnerable workers (García, 2001). ${ }^{1}$

\footnotetext{
1 The sectors accounting for the majority of women in informal employment are commerce (which saw an increase from $31 \%$ in 2000 to $34.3 \%$ in 2009), services (21.3\% in 2009) and manufacturing (13.3\%) (Cardero and Espinosa, 2013).
} 
The informal labour sector includes work done from home for the market. This kind of activity has been going on ever since the start of the industrial revolution and has taken on new forms as it adapts to changes in labour demand. As one crisis follows after another, own-account work has come to represent a large share of the labour participation rates of adult women and their male children (García, 2001). According to the National Occupation and Employment Survey, today this type of work is performed by $14 \%$ of the labour force in Mexico (4.4 million people as of 2010), which means that nearly one third of all informal workers are working from home. Furthermore, the sexual division of labour is clearly reflected in home-based employment, with women homeworkers (10.2\%) far outnumbering their male counterparts $(2.6 \%) .^{2}$ In manufacturing, home-based work is common in the wearing apparel, leather and footwear, furniture and machinery industries; in the services sector, it is prevalent in retail groceries, stationery, clothing and professional services.

By contrast, $12.8 \%$ of all employed males work at the home of their employer, whereas only $3.9 \%$ of employed women do. These employees include domestic workers, drivers and wage earners employed in homebased microenterprises.

This form of gender-based segregation raises an issue in terms of our understanding of what modes of employment are characteristic of home-based employment as opposed to other options, such as working in an office, a factory or some other institution outside the home or of remaining outside the workforce. The objective of this study is to examine the factors influencing men's and women's decisions as to where and how to work ${ }^{3}$ and or whether to remain outside the labour force. More specifically, the options that will be analysed are: home-

\footnotetext{
2 According to the National Occupation and Employment Survey, over $80 \%$ of this type of work takes the form of own-account employment.

3 It is important to remember that women (and some men) engage in unpaid work in their own home (e.g., childcare, caring for older adults in the home, housework, etc.). This kind of domestic work is just as valuable as work done in the marketplace, but, for the sake of clarity and the purposes of this study, the term "home-based work" is used to refer exclusively to paid work performed in the home for the market.
}

based work in the manufacturing or services sectors, working outside the home and not working.

Another objective is to determine how the 2008 crisis affected home-based work and work outside the home. As is well known, Mexico was the hardesthit of all the Latin American countries, with its total GDP and manufacturing sector's GDP plunging by 5.9\% and 9.9\%, respectively, in 2008-2009 (National Institute of Statistics and Geography (INEGI)), while its unemployment rate jumped from $4 \%$ to $5.5 \%$ (a $20 \%$ increase). Informal employment and the substandard conditions associated with it also expanded during that time, and it is therefore to be expected that the scale and determinants of this form of employment have also changed.

In line with Edwards and Field-Hendrey (2002) and Rani and Unni (2009), a multinomial model is used in this study for the years 2005 and 2010. This model makes it possible to undertake a simultaneous analysis of decisions to work from home in the manufacturing or services sectors or outside the home versus decisions to remain outside the workforce. The data source used is the National Occupation and Employment Survey for those same years. The literature on home-based employment in Mexico is very limited, which poses a challenge for any attempt to conduct an econometric analysis of the factors underlying this form of employment in the manufacturing and services sectors. The literature does, however, contain one very interesting study, based on a special-purpose survey, that analyses home-based working conditions in the manufacturing sector, the nature of such work and the accompanying labour relations (see Benería and Roldán, 1992).

As will be discussed in section II, the reasons why home-based employment exists are complex and involve a range of different factors. In section III, we describe the different forms of employment: home-based employment in the manufacturing or services sector, employment outside the home and non-participation in the labour force. The methodology and results of the multinomial model that is used to determine the probability that men or women will choose one or another of these modalities are discussed in section IV. Some final comments and observations are presented in section $\mathrm{V}$. 


\section{II}

\section{Basic aspects of home-based work}

Some Marxist authors have suggested that home-based work has increased in response to the requirements of the globalized capitalist system, in which managers need to be able to outsource goods and services from a flexible, low-cost supply of labour in a way that allows them to bypass labour laws and avoid providing benefits (Pearson, 2004). According to this view, the expansion of home-based employment is an outgrowth of informal labour, which is the crucial factor to take into consideration in order to arrive at an understanding of the relationship between globalized production and home-based employment (Benería, 1981; Carr, Chen and Tate, 2000).

Clearly, trade liberalization has exerted downward pressure on production costs, which increases the attractiveness of outsourcing in the informal sector on disadvantageous terms and conditions for workers (Pearson, 2004; Benería and others, 2000). In Mexico, as in other third-world countries that are part of global value chains in the textile and clothing industry (Dedeoglu, 2010), the presence of maquiladoras has allowed the garment industry to increase its use of outsourced homebased work for specific tasks (sewing on buttons, making hems, sewing on lace and embroidery) (López, 2005; Juárez, 2004). Care should be taken to avoid overstating the importance of international outsourcing as a major reason for the existence of home-based employment, however, since it is known that most exports have a very high content of imported inputs, which puts local suppliers at a disadvantage; this, in turn, depresses local demand for goods and services and weakens the intra- and inter-sectoral links of domestic production chains (Aroche and Cardero, 2007). Outsourcing is thus most common in specific niches, such as, for example, the garment industry, where for each male employee there are 2.65 women, according to data compiled by INEGI.

An additional factor in the appearance of new forms of home-based work in Mexico - especially in the case of highly educated men who work in the services sector - has to do with new ways of organizing production activities based on flexible specialization (Piore and Sabel, 1984) and the technological changes that have ushered in the fragmentation of the production process, the decentralization of production and the vertical de-integration of business enterprises (Gereffi, Humphrey and Sturgeon, 2005; Langlois, 1995), which then opt to purchase certain services in the market that they used to produce in-house. In addition, companies' efforts to establish more flexible working conditions and save both time and space, in conjunction with the growing utilization of information technologies in various easily monitored areas of corporate activity, are opening the way for some of their employees to work from home. The idea of "remote workers" (i.e., employees who work away from the office) has been around for quite some time, but until recently the term was simply a synonym for working from home or teleworking. It is not a question of outsourcing a service but instead of relocating it from the office to a home. Advances in mobile technology are also making virtual meetings (and the savings in travel expenses and working hours associated with them) more and more common (Cerda, 2011).

In this article we will focus on the approach adopted by Atasü Topçuoglu (2005), who believes that the relationships between economic globalization, the increasing scale of informal economic activity and home-based employment are all important factors but are not in themselves sufficient explanations for this phenomenon, which has, after all, been in existence since before the industrial revolution (Thompson, 1963; Louw and De Vries, 2002). The prevalence of patriarchal gender relations is another factor that blocks women from participating in the workforce on an equal footing with men and that contributes to the invisibility of women's informal home-based employment, which is sometimes chosen because there is no alternative, rather than because it is an attractive option. As noted by Hartmann (1979), women occupy a dual position in the labour market. They rely on their husbands' wages, which is why it is they who do the housework, but, at the same time, their household duties place them in a weaker position within the labour market, which translates into lower wages vis-à-vis their male counterparts. In other words, home-based work offers a way for women to work and earn an income without challenging the prevailing patriarchal ideology (Kantor, 2003).

As a result, the labour market is not gender-neutral. There are informal and cultural norms that lead to gender segregation in some sectors of the economy and 
employment, in addition to vertical gender segregation (Elson, 1999). Sociocultural constructs of gender roles and stereotypes establish who the decision-makers are and to whom economic assets belong (Benería and Roldán, 1987).

Viewed from this vantage point, it can be seen that there are a range of variables involved in the explanation of why there is a segment of the population that earns its livelihood through home-based employment. Recent studies have looked at the sociodemographic characteristics of home-based workers (e.g., level of education, age, religion, racial identity and the labour costs of home-based work), which are important considerations in the case of women who, unlike men, have to combine household tasks with their marketbased employment activities. This can mean that the reservation wage may be lower than it is for employment outside the home. A pioneering study by Edwards and Field-Hendrey (2002), in which they used data from the 1990 population census of the United States, is based on the concept that participation in the labour market has a fixed cost and takes a close look at women's decisions about working in the home. They find that women who have children or other dependents or who live in rural areas are more likely to work from home than elsewhere. The study also indicates that women with children, other dependents or a spouse are more likely to engage both in unpaid domestic work and home-based gainful employment. The authors focus on the attractiveness for women of the option of staying at home so that unpaid domestic work can be combined with gainful home-based employment.

Rani and Unni (2009) have used a similar model in analysing the situation in India, but they also take the economic situation into consideration in gauging how important a role economic reforms may have played in the frequency of the practice of outsourcing. They focus on the determinants of men's and women's decisions as to whether to work in the manufacturing or services sectors from home or away from home. The authors find that women's decisions regarding home-based employment are influenced, at a micro level, by their cultural environment (castes, religion), their level of education and the fixed cost of working at home; these considerations are not taken into account by men when making this same decision. In other words, these authors found evidence that corroborates how strongly women are influenced by existing patriarchal systems.

At a macro level, Rani and Unni (2009) compare past periods in which trade was not as open with the situation in more recent times and find that there is no significant correlation for women home-based workers but that there is one for male home-based workers. This suggests that the small but increasing percentage of men engaging in home-based work may be driven by economic reforms that have altered male employees' role in the organization of production. In other words, while the sociocultural factors that influence women's decisions about engaging in home-based employment are quite evident, those that may affect men's decisions in this respect are not, and their decisions may be based on responses to the demand for outsourced labour generated by industries' efforts to cut labour costs in an increasingly globalized market.

On the basis of these two studies, an attempt will be made here to explain the dynamic of home-based and non-home-based work from a gender perspective at both the microand macro levels. A more detailed account will be provided in section IV.

\section{III}

\section{Stylized facts about home-based and non-home- based employment in the manufacturing and services sectors: 2005-2010}

Even though a growing number of women entered the labour market in the late twentieth century, women's participation in the labour force remains fairly limited; only $38 \%$ of women were employed, versus $86 \%$ of men, as of 2005. During the next five years, however, female employment climbed faster than male employment, and the employment figures had therefore changed to $42 \%$ for women and $84 \%$ for men by 2010 , which suggests that 
the crisis had a stronger impact on the latter. The number of women working from home in the manufacturing and services sectors fell slightly, slipping from $15 \%$ of the total in 2005 to $12 \%$ in 2010 (see table 1). The proportion of men working from home remained steady at $3 \%$, but their distribution changed: whereas $5 \%$ of them were working in manufacturing and $1 \%$ in services in 2005 , in 2010 the corresponding percentages were $1 \%$ and $2 \%$, respectively. In other words, there was a $3.7 \%$ annual decrease in the number of men working from home in the manufacturing sector and an increase in those engaged in an own-account home-based services business; even though women's participation rate in this latter category fell by seven percentage points, it continues to be more than twice as high as the overall average (see table 1).

In all, $97 \%$ of men, compared to $85 \%$ of women, worked outside the home (i.e., in a factory or in an office or in the informal sector on the street or in the home of their employer) in 2005; the corresponding figures for 2010 were $97 \%$ and $88 \%$, respectively (see table 1). This means that the percentage of women working outside the home rose slightly during this period, which would not be expected to occur during a crisis. One possible explanation is that these women switched over from doing own-account work to employment in the home of their employer or to working as informal street peddlers or to employment in the formal sector in offices or factories. During this period, the proportion of the total employed labour force represented by women climbed from $32 \%$ to $34 \%$, which is still less than their average participation rate in the economy as a whole.

Over $80 \%$ of the women who are not in the workforce classify themselves as "unavailable for employment" because they are students, are retired or, in the majority of cases, are married and stay at home to take care of their children and the house. The number of men who place themselves in this category is much smaller, as may be seen from table 1 .

In the five-year period under study (see table 1), the number of unemployed persons increased considerably $(12 \%)$, with the rise in joblessness for women (14\%) being sharper than it was for men $(11 \%) .{ }^{4}$ Within this category, the proportion of women who were available

\footnotetext{
4 The unemployment rate was $2.2 \%$ in 2005 and $3.5 \%$ in 2010; the rate for women was slightly higher (2.3\% in 2005 and $3.7 \%$ in 2010, versus $2.2 \%$ and $3.4 \%$, respectively, for men). This unemployment rate is lower than the average rate for the economy because the youth unemployment rate (persons between the ages of 15 and 24) in Mexico has historically been slightly more than twice as high as the rate for persons aged 25 or over, and the subsample includes a larger proportion of people over 25 years of age.
}

for work rose by $5 \%$ and the proportion who were unavailable declined. Just the opposite occurred in the case of men, with the proportion who classified themselves as unavailable increasing by $3 \%$, on average, per year.

Since the focus of this study is on home-based workers, a subsample ${ }^{5}$ of the National Occupation and Employment Survey will be used for the years $2005^{6}$ and 2010 which is composed of heads of household and their spouses. Observations for working-age children or other members of the household have not been included, since it is assumed that they would not be in a position to start up a business in a home that does not belong to them. It is acknowledged that there may be exceptions, with children running a business out of their parents' home, but these cases are not thought to be significant in number.

The National Occupation and Employment Survey covers 105,342 households and then uses an expansion factor to extrapolate the data to the population as a whole. The number of observations in the sample used here was 81,223 male heads of household or spouses and 95,834 female heads of household or spouses. Table 2 provides information on the composition of the households in the sample. As is to be expected, many more men (96\%) than women $(25 \%)$ are heads of household. A large percentage of the households (55\% of male-headed households and $43 \%$ of female-headed households) have dependents in need of care (defined as children below the age of 12 and older adults living in the household who do not work). ${ }^{7}$ Most of these dependents are children.

Male and female workers exhibit different distributions of various attributes (see tables 3 and 4). Men who are not in the workforce tend to be over 45 years of age $(80 \%)$, which may be due to the difficulty that older men have in finding a job. The age distribution of women who are not in the workforce, on the other hand, is fairly even, which reflects many women's decision to take care of their children rather than to work, as has been corroborated by numerous studies (Maldonado and Rendón, 2004). The age group which has the largest number of home-based workers for both men and women is 35-44 years, but men tend to work until they are over 60 , which is not the case for women. Women who work outside the home tend to be younger than their male

\footnotetext{
5 This is a subsample because the National Occupation and Employment Survey gathers information on all members of each household. In the remainder of this article, however, this subsample will be referred to simply as "the sample".

6 This survey was first conducted in 2005 .

7 This group was defined as jobless persons over 65 years of age.
} 


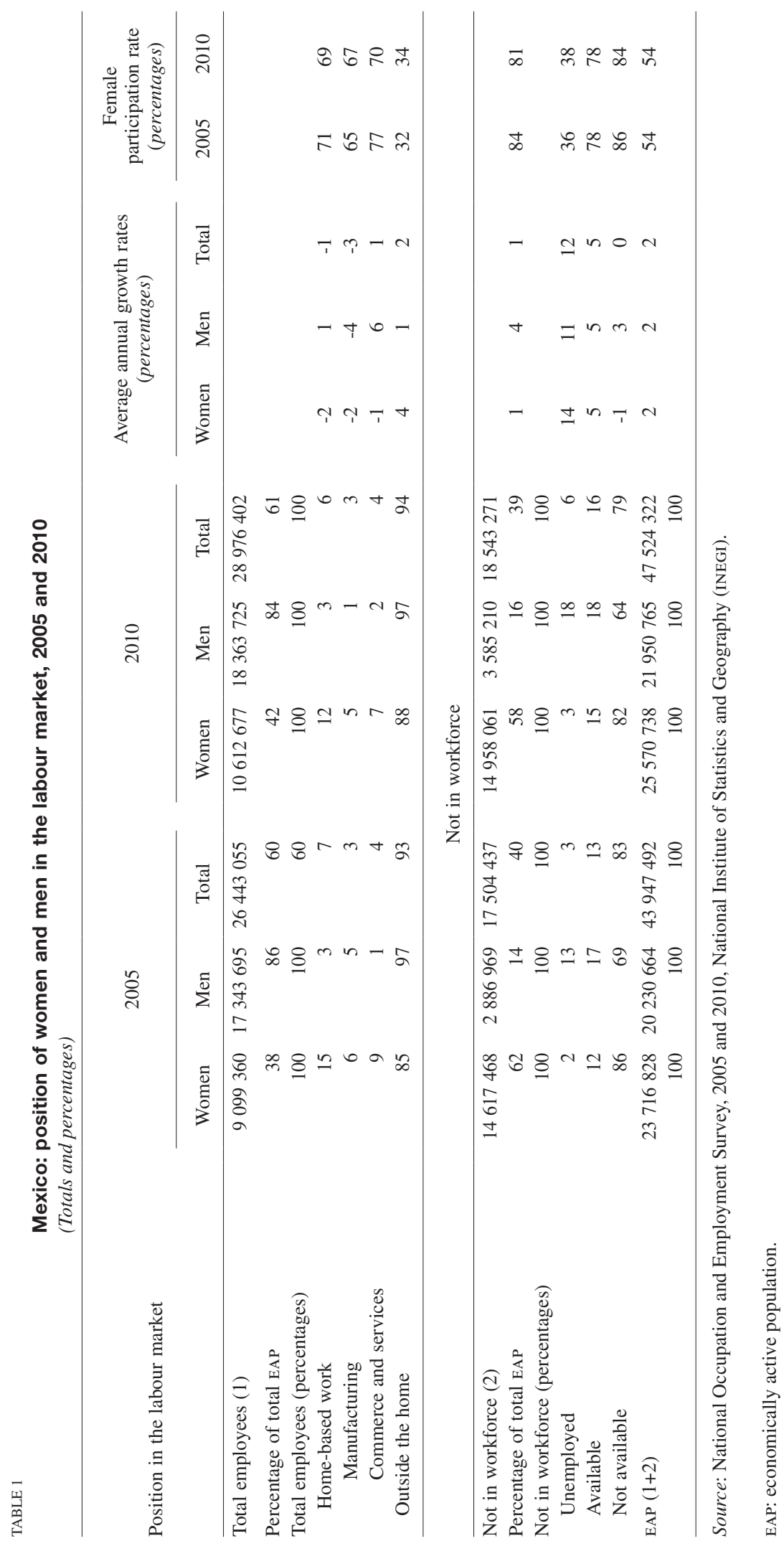


TABLE 2

Mexico: composition of households

in the sample

(Percentages)

\begin{tabular}{lcc}
\hline & \multicolumn{2}{c}{ Average: 2005-2010 } \\
\cline { 2 - 3 } & Men & Women \\
\hline Head of household & 96 & 25 \\
Spouse & 4 & 75 \\
Children 7 years of age or younger & 22 & 19 \\
Children aged 8 to 12 & 24 & 20 \\
Adult dependents & 8 & 3 \\
Total & 55 & 43 \\
\hline
\end{tabular}

Source: National Occupation and Employment Survey, 2005 and 2010, National Institute of Statistics and Geography (INEGI). counterparts (most of these women areunder 45 years of age) and younger than female home-based workers.

One of the changes that can be seen to have taken place during this five-year period is that the people who started up a business in their homes tended to be older. This was particularly true of women. Home-based employment in manufacturing or services accounted for $34 \%$ of the total for women in the 45 -years-and-over age group in 2005, and this figure had risen to nearly $50 \%$ by 2010 , whereas for men the corresponding increase was from $50 \%$ to $58 \%$. The question arises as to whether or not this trend is attributable to the scarcity of job opportunities during the crisis.

Generally speaking, higher levels of education correlate with higher incomes and better working

TABLE 3

Mexico: characteristics of female workers, 2005 and 2010

(Percentages of the total)

\begin{tabular}{|c|c|c|c|c|c|c|c|c|}
\hline \multirow{2}{*}{ Women } & \multicolumn{2}{|c|}{ Not in workforce } & \multicolumn{2}{|c|}{$\begin{array}{l}\text { Home-based work } \\
\text { in manufacturing }\end{array}$} & \multicolumn{2}{|c|}{$\begin{array}{c}\text { Home-based work } \\
\text { in services }\end{array}$} & \multicolumn{2}{|c|}{ Outside the home } \\
\hline & 2005 & 2010 & 2005 & 2010 & 2005 & 2010 & 2005 & 2010 \\
\hline \multicolumn{9}{|l|}{ Age groups } \\
\hline $15-25$ years & 10 & 9 & 8 & 4 & 6 & 4 & 5 & 6 \\
\hline 25-35 years & 22 & 19 & 29 & 20 & 25 & 18 & 25 & 23 \\
\hline $35-45$ years & 22 & 20 & 33 & 28 & 31 & 27 & 37 & 33 \\
\hline $45-60$ years & 26 & 27 & 23 & 33 & 29 & 35 & 28 & 31 \\
\hline Over 60 years & 20 & 25 & 7 & 15 & 9 & 16 & 5 & 7 \\
\hline Total & 100 & 100 & 100 & 100 & 100 & 100 & 100 & 100 \\
\hline \multicolumn{9}{|l|}{ Levels of education } \\
\hline Less than primary & 12 & 11 & 10 & 15 & 8 & 9 & 6 & 5 \\
\hline Primary & 46 & 41 & 42 & 47 & 40 & 43 & 25 & 26 \\
\hline Lower-secondary & 20 & 23 & 27 & 22 & 23 & 24 & 15 & 23 \\
\hline Upper-secondary or technical school & 7 & 9 & 7 & 7 & 9 & 9 & 10 & 13 \\
\hline Professional & 15 & 16 & 14 & 9 & 20 & 15 & 44 & 33 \\
\hline Total & 100 & 100 & 100 & 100 & 100 & 100 & 100 & 100 \\
\hline \multicolumn{9}{|l|}{ Marital status } \\
\hline Single & 3 & 4 & 7 & 5 & 10 & 6 & 3 & 11 \\
\hline Married & 71 & 67 & 64 & 64 & 60 & 61 & 71 & 58 \\
\hline Consensual union & 13 & 15 & 11 & 13 & 11 & 13 & 13 & 14 \\
\hline Separated & 3 & 3 & 7 & 6 & 8 & 7 & 3 & 7 \\
\hline Widow & 9 & 10 & 8 & 10 & 6 & 10 & 9 & 6 \\
\hline Divorced & 1 & 1 & 3 & 2 & 5 & 3 & 1 & 4 \\
\hline Total & 100 & 100 & 100 & 100 & 100 & 100 & 100 & 100 \\
\hline \multicolumn{9}{|l|}{ Size of place of residence } \\
\hline Population of over 100000 & 57 & 55 & 63 & 36 & 68 & 57 & 57 & 65 \\
\hline Population between 15000 and 99000 & 12 & 12 & 14 & 13 & 12 & 13 & 12 & 13 \\
\hline Population between 2500 and 14999 & 12 & 12 & 12 & 21 & 10 & 13 & 12 & 11 \\
\hline Population of less than 2500 & 19 & 21 & 11 & 30 & 10 & 17 & 19 & 11 \\
\hline Total & 100 & 100 & 100 & 100 & 100 & 100 & 100 & 100 \\
\hline
\end{tabular}

Source: National Occupation and Employment Survey, 2005 and 2010, National Institute of Statistics and Geography (INEGI). 
Mexico: characteristics of male workers, 2005 and 2010

(Percentages of total)

\begin{tabular}{|c|c|c|c|c|c|c|c|c|}
\hline \multirow[t]{2}{*}{ Men } & \multicolumn{2}{|c|}{ Not in workforce } & \multicolumn{2}{|c|}{$\begin{array}{l}\text { Home-based work } \\
\text { in manufacturing }\end{array}$} & \multicolumn{2}{|c|}{$\begin{array}{c}\text { Home-based work } \\
\text { in services }\end{array}$} & \multicolumn{2}{|c|}{ Outside the home } \\
\hline & 2005 & 2010 & 2005 & 2010 & 2005 & 2010 & 2005 & 2010 \\
\hline \multicolumn{9}{|l|}{ Age groups } \\
\hline $15-25$ years & 4 & 4 & 4 & 2 & 3 & 2 & 3 & 6 \\
\hline $25-35$ years & 6 & 6 & 20 & 15 & 18 & 13 & 18 & 22 \\
\hline $35-45$ years & 9 & 10 & 26 & 28 & 25 & 25 & 25 & 29 \\
\hline $45-60$ years & 21 & 23 & 32 & 35 & 35 & 38 & 35 & 32 \\
\hline Over 60 years & 60 & 57 & 18 & 20 & 19 & 22 & 19 & 11 \\
\hline Total & 100 & 100 & 100 & 100 & 100 & 100 & 100 & 100 \\
\hline \multicolumn{9}{|l|}{ Levels of education } \\
\hline Less than primary & 17 & 13 & 5 & 7 & 7 & 5 & 17 & 5 \\
\hline Primary & 48 & 44 & 30 & 46 & 37 & 30 & 48 & 32 \\
\hline Lower-secondary & 12 & 15 & 22 & 28 & 21 & 21 & 12 & 26 \\
\hline Upper-secondary or technical school & 6 & 8 & 14 & 11 & 12 & 12 & 6 & 14 \\
\hline Professional & 17 & 20 & 29 & 8 & 23 & 32 & 17 & 23 \\
\hline Total & 100 & 100 & 100 & 100 & 100 & 100 & 100 & 100 \\
\hline \multicolumn{9}{|l|}{ Marital status } \\
\hline Single & 7 & 9 & 4 & 4 & 6 & 7 & 4 & 5 \\
\hline Married & 72 & 70 & 81 & 73 & 75 & 68 & 76 & 72 \\
\hline Consensual union & 8 & 10 & 12 & 16 & 14 & 16 & 15 & 18 \\
\hline Separated & 3 & 2 & 1 & 3 & 2 & 4 & 2 & 2 \\
\hline Widower & 9 & 8 & 1 & 2 & 2 & 3 & 2 & 2 \\
\hline Divorced & 1 & 1 & 1 & 2 & 1 & 2 & 1 & 1 \\
\hline Total & 100 & 100 & 100 & 100 & 100 & 101 & 100 & 100 \\
\hline \multicolumn{9}{|l|}{ Size of place of residence } \\
\hline Population of over 100000 & 64 & 61 & 70 & 51 & 55 & 66 & 62 & 57 \\
\hline Population between 15000 and 99000 & 15 & 11 & 14 & 16 & 12 & 13 & 12 & 12 \\
\hline Population between 2500 and 14999 & 11 & 12 & 10 & 16 & 12 & 10 & 11 & 12 \\
\hline Population of less than 2500 & 10 & 16 & 7 & 17 & 21 & 11 & 15 & 19 \\
\hline Total & 100 & 100 & 100 & 100 & 100 & 100 & 100 & 100 \\
\hline
\end{tabular}

Source: National Occupation and Employment Survey, 2005 and 2010, National Institute of Statistics and Geography (INEGI).

conditions; education has also proven to be a highly important factor in women's decisions to enter the labour market (Maldonado and Rendón, 2004). If a lower-secondary-school education or less is taken as a point of reference, then, as is to be expected, the figures show that men and women who are not participating in the workforce tend to be less educated, with some $25 \%$ having a primary-school education. In the case of female home-based workers, $77 \%$ have not completed upper-secondary school. In the case of more highly educated workers, in 2005 the percentage of men engaged in home-based employment in manufacturing and especially in services was larger than the percentage of women engaged in these activities. Interestingly, the proportion of heads of household with completed uppersecondary and/or specialized educations increased from
$35 \%$ to $44 \%$. This could stem from the decentralization of production and the vertical de-integration of businesses that was referred to earlier. It could also reflect more highly educated people's decision to opt for selfemployment in response to the crisis. Yet another factor is likely to have been that people with more schooling may often be more driven to improve their situation and achieve financial independence (García and Pacheco, 2000). This is in line with the fact that women heads of households working outside the home are more highly educated than female home-based workers and than their male counterparts.

Tables 3 and 4 indicate that marriage is the most common marital status, followed by consensual unions. With the exception of unemployed persons, in all other categories there are more men than women, which means 
that there are more employed women without partners; women who are separated or divorced, in particular, tend to be working, either in the home or elsewhere. ${ }^{8}$ Because of the family responsibilities that go along with marriage, it is to be expected that a smaller percentage of married women are employed (García and De Oliveira, 1994). Thus, whereas $84 \%$ and $82 \%$ of unemployed women were married or in a consensual union in 2005 and 2010, respectively, the corresponding figures for employed women were $76 \%$ and $74 \%$ for those same years. This differential is not present among men. Over the period covered by the study, there was a continuous increase in the proportion of married women who worked from

8 Whereas $13 \%$ of single women were unemployed in 2005 and $14 \%$ were in 2010, the percentage of single women working in any of the types of activities analysed in this study rose, on average, from $16 \%$ in 2005 to $18 \%$ in 2010 . home and a continuous decrease in the proportion who worked outside the home or were unemployed.

Finally, it is also important to analyse the rural/ urban distribution of the population in order to take account of the advantages or disadvantages associated with residence in a location having different levels of access to services, different cultures and traditions, and differing ranges of job opportunities.

The percentage of men tends to be higher in urbanized areas. Much of the home-based work that is performed takes place in large cities, especially in the services sector, which is where two thirds of male and female heads of household are employed. Over the period of analysis, this trend in the services sector became more and more marked. This was not the case for the manufacturing sector, where $62 \%$ of female heads of household were working from home in large cities in 2005 whereas only $36 \%$ were doing so in 2010 . The trend for male heads of household was similar. In other words, home-based work in the manufacturing sector became less urbanized.

\section{IV}

\section{The decision to work from home:}

\section{a multinomial model}

\section{Methodology}

The multinomial logit model that was used in this study is based on the idea that the four different options (home-based work in the manufacturing or services sectors, non-home-based employment and non-participation in the labour market) have no hierarchical order. The purpose of using this model was to compute the probability of an individual opting for any one of these alternatives. The explanatory variables are exogenous factors that influence labour supply under all the circumstances mentioned: reservation wage, fixed costs of working outside the home and macroeconomic conditions.

In order to estimate the first variable, we look at age, level of schooling and how urbanized the worker's area of residence is, which can be used to express the cost of commuting. As various authors have noted, individuals gain personal and work experience as they age that enhances their employability; however, it is also true that, after a point, the ageing process is associated with a physical and intellectual deterioration that can lessen older adults' chances of continuing to be economically active (Millán, 2010). Thus, the effects of age can be expected to be non-linear, since the reservation wage will increase with age up to a point and will then begin to decrease with age.

In addition, higher levels of schooling can be expected to be associated with a greater likelihood that a person will work outside the home, and home-based work can be expected to be associated with lower levels of schooling than non-home-based employment.

As compared to residents of urban zones, people residing in less urbanized areas have a lower reservation wage for home-based-work than for non-home-based work. There are fewer job opportunities in rural areas, however, and working from home in the services industry in such areas is not common; it is more likely that rural home-based workers will be employed in the manufacturing sector. Because of commuting costs, it is to be expected that there will be a greater probability that people in urban areas will work from home in the services sector or will work outside the home (Rani and Unni, 2009). 
The fixed costs involved here are represented by variables relating to reproductive labour and the work involved in caring for children and other dependents. Because the presence of dependents raises the level of fixed costs, it can be expected to increase the probability that the person concerned will choose to work from home rather than not participating in the labour force and to decrease the probability that such a person will work outside the home. The fact that a person has a partner may result in increased housework and therefore be an obstacle to undertaking a job, but especially a job outside the home. Since women have traditionally shouldered the responsibility of caring for the home, a link is not expected to exist between these variables and men's decisions regarding employment. Some studies suggest that the presence of adult dependents in the home can lighten the childcare workload (Knaul and Parker, 1997), but if the older adults are in poor health, fixed costs may be greater because the need to care for them could be an impediment to employment. Other studies have not found evidence of this (García and Pacheco, 2000).

Other factors that could influence women's participation in the labour market are fluctuations in employment levels and the business cycle (Bover and Arellano, 1995).

In this study, macroeconomic conditions are represented by GDP growth at the state level, weighted by the labour-force participation rate. ${ }^{9}$ On a macroeconomic

9 Reliable statistics on home-based work prior to 2005 are unavailable, so this exercise cannot be performed for prior periods. scale, if home-based work is a refuge from unemployment, then the number of people engaged in such work would be expected to rise sharply in states where GDP growth is low or average. On the other hand, if home-based labour is a supplement for formal-sector businesses that subcontract informal labour or outsource goods and services, then it would be expected to be more prevalent in states where GDP growth is high or average. There is no a priori hypothesis for male/female differentials.

Finally, we posit that the financial difficulties triggered by the crisis may have altered the way in which some variables influence the probability of homebased employment. For example, Anderson and Levine (1999) find that the presence of young children in the home and the associated cost of childcare will lessen the probability of participation in the labour market. This would mean that, for women, the crisis may have increased the probability that they would work from home and reduce the probability that they would engage in employment outside the home. On the other hand, if the crisis has depressed the level of household income, the presence of small children may be a less influential factor in adult women's decision to join the labour force (García and De Oliveira, 1994).

The model's dependent variable uses a number of values: "1" for home-based employment in the manufacturing sector; " 2 " for home-based employment in the services sector; " 3 " for employment outside the home; and "4" for non-participation in the labour market. The description of the variables used for each group is given in table 5 .

TABLE 5

Independent variables of the multi-logit model

\begin{tabular}{|c|c|c|}
\hline Reservation wage & Fixed costs of working outside the home & Macroeconomic conditions \\
\hline Age & Children 7 years of age or younger $=1$ & $\begin{array}{l}\text { Low-growth states: } \\
\text { GDP growth lower than } 4.14=1\end{array}$ \\
\hline $\mathrm{Age}^{2}$ & Children aged 8 to 12 years $=1$ & $\begin{array}{l}\text { Average-growth states: } \\
\text { GDP growth of } 4.15 \text { or higher }=1\end{array}$ \\
\hline $\begin{array}{l}\text { Level of education: } \\
\text { Up to primary }=1\end{array}$ & $\begin{array}{l}\text { Dependent older adults } \\
\text { (over } 65 \text { years of age and not working) }=1\end{array}$ & $\begin{array}{l}\text { High-growth states: } \\
\text { GDP growth of } 9.04 \text { or higher }\end{array}$ \\
\hline $\begin{array}{l}\text { Level of education: } \\
1 \text { st to 3rd of lower-secondary }=1\end{array}$ & Married $=1$ & \\
\hline $\begin{array}{l}\text { Level of education: } \\
\text { Upper-secondary }=1\end{array}$ & Single $=1$ & \\
\hline $\begin{array}{l}\text { Level of education: } \\
\text { University or postgraduate degree }\end{array}$ & Consensual union $=1$ & \\
\hline \multirow[t]{2}{*}{ Place of residence: population $>100000=1$} & Divorced $=1$ & \\
\hline & Widow/widower $+=1$ & \\
\hline
\end{tabular}

Source: prepared by the authors.

GDP: gross domestic product. 


\section{Results of the estimation of the model}

Four multi-logit regressions were run: one for women and one for men in 2005 and one for women and one for men in 2010. Each regression yielded results for the four different employment options. There were 78,279 observations in 2005 and 75,950 in 2010 for female heads of household, and 64,116 observations in 2005 and 59,342 in 2010 for male heads of household. ${ }^{10}$ In order to avoid any bias that might be generated by the heterogeneity of the population concerned, standard errors were estimated using the robust method developed by Huber and White (Huber, 1967; White, 1982; Langlois, 1995).

All the results were satisfactory except those for the regression for males in 2005 . The pseudo $\mathrm{R}^{2}$ for the multinomial logistic regression, which measures the relationship between the likelihood value of the model as a whole vis-à-vis the restricted model with constants for 2005 and 2010, was $9.3 \%$ in both years for women and 3.6\% for men in 2005 and $15.7 \%$ for men in 2010 . The coefficients as a whole were statistically significant in all four regressions as measured using the Wald test statistic. Since this is a non-linear model, the interpretation of the coefficients is not straightforward. For example, a positive coefficient does not necessarily imply an increased probability. The results in terms of the marginal effects that imply a change in probability due to a modification in a unit of the independent variables will therefore be presented here. These results are shown in tables 6 and $7 .{ }^{11}$

\section{(a) Reservation wage}

Both women and men who have completed secondary or higher education were less likely to decide to take a home-based job in the manufacturing sector in either 2005 or 2010, which indicates that this type of job has a low reservation wage because of its largely unskilled nature. By the same token, the marginal effect on the probability of home-based work in the services sector was negative in both those years for more highly educated women heads of household (those who hold a university or postgraduate degree), with marginal effects of -1.0 in 2005 and -1.2 in 2010. More educated men were more likely than their female counterparts to engage in home-based work in the services sector in both 2005 and 2010, however. In fact, the marginal effects on the likelihood of this

\footnotetext{
10 The sTATA software that was used to compute the estimates, discards an observation if full information for some variables is lacking. See Stata User's Guide, Release 12 [online].

11 These estimates are given in the annex.
}

form of home-based employment were 0.03 and 0.08 for persons who have completed upper-secondary school and 0.65 and 0.43 for those with specialized educations. The latter can be regarded as a high-valueadded niche market (consultancies, work performed by architects, doctors, lawyers and information technologies specialists, among others) that is being supplied by outsourced services by own-account or remote workers, as noted earlier.

The probability of working outside the home is negatively correlated with low levels of education, while there is a clear preference among women who have a specialized education (marginal effects of 22.54 and 19.33) or who have completed their upper-secondary education (9.48 and 9.34 in 2005 and 2010, respectively) to work outside the home, although this preference was slightly less marked in 2010 than it was in 2005. This was not the case for heads of household, for whom the marginal effects were smaller or negative: -3.87 and 1.38 for those holding a university degree and -1.63 and 1.39 for those holding an upper-secondary-school diploma. These results corroborate other studies' findings regarding the importance of a more advanced education for women (García and Pacheco, 2000) and suggest that, whereas men consider other factors when deciding to work outside the home, for more highly educated women, their education is a very influential factor in their choice of such occupations.

Apart from the labour force, the positive marginal effects for men of having completed upper-secondary school or university were quite strong in 2005 (2.03 and 4.65); this was not the case for men with a university degree in 2010, although the marginal effect was very small and may have been attributable to their acceptance of lower-paying jobs. The figures back up the hypothesis that women with low levels of education account for a larger percentage of the unemployed. While the marginal effect of having no more than a primary education is, on average, 3.6, the marginal effects of having a university or postgraduate education are -20 and 26 , respectively. In other words, the more educated a woman is, the less likely she is to be unemployed (see tables 6 and 7).

As was expected, the regressions for home-based work for both men and women reflect a non-linear relationship with age in 2005 and in 2010. This is true for all of the three options being analysed here. There are some subtleties that should be noted, however. On the one hand, the marginal effect of age on the probability of working from the home is greater for female heads of household, which means that these women tend 
to continue to participate in the labour market when they are older. On the other hand, during the period of analysis there was an increase in the probability that people would be working at an older age, and this was particularly true of women heads of household. There were two exceptions, however: heads of household who work from home in the manufacturing sector, where the marginal effect on this probability declined from 0.08 to 0.06 , and women working in the services sector (with a decrease from 0.28 to 0.26 ).

Age was associated with a lower probability of being unemployed in 2010 than in 2005, but this effect was not apparent in the case of women. In fact, the unemployment rate tended to increase more sharply for women than for men once the turning point in the agerelated trend was reached. If men are seen as the sole breadwinner, then it could be that, as older adults, they are regarded as the ones who should earn the income needed to meet the needs and demands of the family members with whom they live (Millán, 2010).

In terms of commuting costs, the probability that women will work from their homes in the manufacturing sector is negatively correlated — slightly less so in 2010 than in 2005 - with an increased degree of urbanization (the marginal effects are -1.40 and -1.35). In the case of men, this variable was significant only in 2010 and to a lesser degree $(-0.11)$. This suggests that female heads of household who live in less urbanized areas attach considerable value to not having to travel to workplaces outside their homes; in some cases, the materials that they need in order to do their work are delivered to them, as is the practice in the clothing industry, while, in others, they are creating indigenous craftwork. Unlike home-based employment in the manufacturing sector, in the two years under study, home-based work in the services industry was primarily practised in more urbanized areas (with populations of over 100,000); this was true both of women (marginal effects of 0.38 and 0.37 ) and of men (0.40 and 0.32 ), although there was a decline in 2010 (see tables 6 and 7$)$.

The probability that women heads of household will work outside the home in these areas was greater, particularly in 2010 (3.88 and 7.23). For male heads of household, the effect was positive in 2005 (3.18), but negative in $2010(-2.41)$. One possible reason could be that male post-crisis unemployment rates were higher in more urbanized areas. Finally, women living in unurbanized areas were more likely to remain outside the workforce; this was generally true of men in 2005 as well, but not in 2010 .

\section{(b) Fixed labour costs}

The presence of small children (under 8 years of age) did not influence the probability of female heads of household engaging in home-based work in the manufacturing sector and had very little influence in the case of employment in services (0.32) in 2010. However, the presence of small children did reduce the likelihood that they would engage in employment outside the home by a factor of nearly 20 in 2005 and 2010 (-5.23 and -6.17). The probability that women with small children would be unemployed in the two years under analysis was thus quite high (5.13 and 5.76). For men, the marginal effects were not significant for the manufacturing sector or the services sector. No clear pattern emerges for the effect that this variable has on the probability of working outside the home or remaining outside the workforce altogether, since these values were statistically significant only in 2010 and were negative in one case $(-0.73)$ and positive in the other $(0.64)$. The data therefore confirm that the presence of small children limits women's participation in the labour market, but not necessarily their participation in home-based employment. Unlike García and De Oliveira (1994), we found no evidence that the difficulty of working when one has small children decreases during hard economic times.

In the case of children between the ages of 8 and 12 , the results for women were as expected, with the presence of children in this age bracket being compatible with home-based work in the manufacturing and services sectors in both 2005 and 2010; their presence appears to have been an obstacle to women's involvement in work outside the home only in 2005, which suggests that the crisis motivated women to enter the labour market, as their probability of being unemployed declined (-0.90) as a result. The results for men were once again statistically significant. The difference between the higher marginal effect for women and the lower marginal effect for men confirms that women end up shouldering most of the responsibility for childcare.

The effect which involvement in a consensual union or marriage has on the probability of working in or outside the home differed substantially between the sexes. The marginal effects were negative in both years for women heads of household who were married or in a consensual union and were greater in respect of work outside the home (-20.1 and -16.5 , on average, respectively) and unemployment (21.5 and 18.0, on average). No correlation was found for women between being single and the probability of home-based employment, but there was a correlation being their single status and the probability that they were working outside the home. Thus, women 
Marginal effects of the estimates for women: 2005-2010

\begin{tabular}{|c|c|c|c|c|c|c|c|c|}
\hline & \multicolumn{2}{|c|}{$\begin{array}{l}\text { Home-based work } \\
\text { in manufacturing }\end{array}$} & \multicolumn{2}{|c|}{$\begin{array}{l}\text { Home-based work } \\
\text { in services }\end{array}$} & \multicolumn{2}{|c|}{ Outside the home } & \multicolumn{2}{|c|}{ Not in workforce } \\
\hline & 2005 & 2010 & 2005 & 2010 & 2005 & 2010 & 2005 & 2010 \\
\hline Primary & 0.09 & 0.11 & $-0.15^{*}$ & 0.37 & $-3.67 * * *$ & $-4.08 * * *$ & $3.73 * * *$ & $3.60 * * *$ \\
\hline Upper-secondary & $-0.63 * *$ & $-0.57 * * *$ & -0.31 & -0.40 & $9.48 * * *$ & $9.34 * * *$ & $-8.55 * * *$ & $-8.37 * * *$ \\
\hline University or postgraduate & $-1.27 * * *$ & $-1.17 * * *$ & -1.0 & $-1.23 * * *$ & $22.54 * * *$ & $19.33^{* * *}$ & $-20.26^{* * * *}$ & $-16.93 * * *$ \\
\hline Age & $0.13 * * *$ & $0.14 * * *$ & $0.28 * * *$ & $0.26^{* * *}$ & $3.85 * * *$ & $4.00 * * *$ & $-4.26 * * *$ & $-4.40 * * *$ \\
\hline $\mathrm{Age}^{2}$ & $0.00 * * *$ & $0.00 * * *$ & $0.00 * * *$ & $0.00 * * *$ & $-0.05 * * *$ & $-0.05 * * *$ & $0.05^{* * *}$ & $0.06^{* * *}$ \\
\hline Place of residence & $-1.41 * * *$ & $-1.35 * * *$ & $0.38 * * *$ & $0.37 * *$ & $3.88 * * *$ & $7.23 * * *$ & $-2.85 * * *$ & $-6.24 * * *$ \\
\hline Children aged 7 years or younger & 0.05 & 0.32 & $0.04 * *$ & 0.1 & $-5.23 * * *$ & $-6.17 * * *$ & $5.13 * * *$ & $5.76^{* * *}$ \\
\hline Children aged 8 to 12 years & $0.23 * * *$ & $0.38 * * *$ & 0.15 & $0.28 *$ & $-0.65 * *$ & 0.24 & 0.27 & $-0.90 * *$ \\
\hline Consensual union & $-0.45^{* *}$ & $-0.41 *$ & $-1.20 * * *$ & $-0.91 * * *$ & $-16.26 * * *$ & $-16.80 * * *$ & $17.91 * * *$ & $18.13 * * *$ \\
\hline Married & $0.56^{* * * *}$ & $-0.15^{* * *}$ & $-1.19 * * *$ & $-0.90 * * *$ & $-20.12 * * *$ & $-20.25 * * *$ & $21.87 * * *$ & $21.30 * * *$ \\
\hline Divorced & 0.43 & -0.3 & $0.98 * * *$ & 0.08 & $12.53 * * *$ & $8.57 * * *$ & $-13.94 * * *$ & $-8.36 * * *$ \\
\hline Separated & 0.45 & 0.39 & $1.80 * * *$ & 0.37 & $11.51 * * *$ & $10.16 * * *$ & $-13.76^{* * * *}$ & $-10.91 * * *$ \\
\hline Single & 0.32 & 0.38 & $1.10 * *$ & 0.18 & $14.72 * * *$ & $14.41 * * *$ & $-16.13 * * *$ & $-14.96^{* * * *}$ \\
\hline Low-growth state & $0.30 * *$ & $0.43 * * *$ & -0.03 & 0.23 & $1.99 * * *$ & $2.88 * * *$ & $-2.25 * * *$ & $-3.53 * * *$ \\
\hline Average-growth state & $1.60 * * *$ & $1.61 * * *$ & $1.70 * * *$ & $1.30 * * *$ & $1.15^{* *}$ & $1.08 * *$ & $-4.45 * * *$ & $-3.99 * * *$ \\
\hline
\end{tabular}

Source: estimates computed on the basis of information from the National Occupation and Employment Survey and from the National Institute of Statistics and Geography (INEGI).

Note: $\mathrm{p}^{* * *}<0.01 ; \mathrm{p}^{* *}<0.05 ; \mathrm{p}^{*}<0.10$

TABLE 7

Marginal effects of the estimates for men: $2005-2010$

\begin{tabular}{|c|c|c|c|c|c|c|c|c|}
\hline & \multicolumn{2}{|c|}{$\begin{array}{l}\text { Home-based work } \\
\text { in manufacturing }\end{array}$} & \multicolumn{2}{|c|}{$\begin{array}{l}\text { Home-based work } \\
\text { in services }\end{array}$} & \multicolumn{2}{|c|}{ Outside the home } & \multicolumn{2}{|c|}{ Not in workforce } \\
\hline & 2005 & 2010 & 2005 & 2010 & 2005 & 2010 & 2005 & 2010 \\
\hline Primary & 0.17 & 0.04 & -0.08 & -0.19 & $-1.45 * * *$ & $-0.91 * * *$ & $1.36 * * *$ & $1.05 * * *$ \\
\hline Upper-secondary & $-0.43 * *$ & -0.24 & $0.03 *$ & $0.08^{*}$ & $-1.63 * * *$ & $1.39 * * *$ & $2.03 * * *$ & $-1.23 * * *$ \\
\hline University or postgraduate & $-1.43 * * *$ & $-0.97 * * *$ & $0.65 * * *$ & $0.43^{* * *}$ & $-3.87 * * *$ & $1.38 * * *$ & $4.65 * * *$ & $-0.84 * *$ \\
\hline Age & $0.08 * * *$ & $0.06 * * *$ & $0.04 * *$ & $0.11 * * *$ & $0.29 * * *$ & $0.42 * * *$ & $-0.41 * * *$ & $-0.58 * * *$ \\
\hline $\mathrm{Age}^{2}$ & $0.00 * * *$ & $0.00 *$ & $0.00 * * *$ & $0.00 * * *$ & $-0.01 * * *$ & $-0.01 * * *$ & $0.01 * * *$ & $0.01 * * *$ \\
\hline Place of residence & -0.01 & $-0.11 * * *$ & $0.40 * *$ & 0.32 & $3.18 * * *$ & $-2.41 * * *$ & $-3.57 * * *$ & $2.20 * * *$ \\
\hline Children aged 7 years or younger & -0.02 & 0.13 & -0.06 & -0.04 & -0.1 & $-0.73 * * *$ & 0.18 & $0.64 * * *$ \\
\hline Children aged 8 to 12 years & 0.01 & 0.05 & 0.06 & 0.02 & -0.4 & $1.19 * * *$ & $0.33^{*}$ & $-1.26 * * *$ \\
\hline Consensual union & 0.08 & 0.35 & 0.57 & 0.29 & $-5.16^{* * *}$ & 0.07 & $4.51 * * *$ & -0.7 \\
\hline Married & 0.01 & 0.46 & 0.24 & -0.07 & -1.29 & 0.65 & 1.03 & -1.03 \\
\hline Divorced & 1.83 & 0.92 & 0.83 & 0.52 & $-5.31 * * *$ & -3.85 & 2.65 & 2.41 \\
\hline Separated & -0.04 & 1.97 & 0.81 & 1.75 & $-3.27 * *$ & -1.43 & 2.51 & -2.29 \\
\hline Single & 0.13 & -0.26 & -0.27 & -0.54 & 1.07 & 0.92 & -0.94 & -0.13 \\
\hline Low-growth state & -0.11 & -0.06 & $-0.25^{*}$ & $-0.25 * *$ & $-1.92 * * *$ & -0.05 & $2.27 * * *$ & 0.36 \\
\hline Average-growth state & 0.08 & $0.19 *$ & -0.1 & 0.03 & $-3.66 * * *$ & $1.14 * * *$ & $3.69 * * *$ & $-1.37 * * *$ \\
\hline
\end{tabular}

Source: estimates computed on the basis of information from the National Occupation and Employment Survey and from the National Institute of Statistics and Geography (INEGI).

Note: $\mathrm{p}^{* * *}<0.01 ; \mathrm{p}^{* *}<0.05 ; \mathrm{p}^{*}<0.10$. 
who do not have a partner are more likely to participate in the labour market. For men, these variables were not statistically significant in most cases, as was to be expected (see tables 6 and 7).

\section{(c) Macroeconomic environment}

Finally, the economic environment in which these activities take place — which is represented in the model by GDP growth in the states where these activities are located - has a positive marginal effect on the probability of women heads of household engaging in home-based employment in the manufacturing sector in the slowgrowth states and a lesser one on this probability in states with average growth rates. This suggests that, to some extent, home-based employment constitutes a refuge for people who are unable to find other types of work. If we were dealing with outsourcing, there would be no reason for it to be confined to states where the pace of economic growth is slow - in fact, just the opposite would be expected.

In the case of services, this factor was significant for women in states with average growth rates, although the marginal effect was weaker than it was for the manufacturing sector. These patterns were not in evidence for men, however, for whom a negative marginal effect was associated with the probability of working in the services industry from home in low-growth states; this suggests that much of this type of employment is found in high-growth states and that it may take the form of outsourcing or of home offices. For women, the probability of working outside the home is greater in slow-growth states than in average-growth ones. Just the opposite occurs in the case of men, where the probability of working outside the home was negative in slow-growth states in both of the years under study, while it was negative in average-growth states in 2005 but was positive in 2010. Finally, the probability of being unemployed is higher in high-growth states for women and lower in those states for men.

These results tell us something about the effect that adverse economic conditions can have. One possible explanation is that, in a negative macroeconomic environment, it becomes more necessary for women to find employment in order to supplement their households' incomes, either because job opportunities are in scarce supply or because their husbands and/or children have migrated to the United States. ${ }^{12}$ On the other hand, the results for male employment suggest that economic growth boosts outsourcing and the demand for consultancies and that home-based work does not necessarily serve as a refuge from a shortfall of job opportunities.

12 Six of the 12 low-growth states belong to the group of states which have the highest migration rates.

\section{Final considerations}

While forms of employment that date back to the industrial revolution still exist, including the exploitative sweatshops discussed by Marx in Das Kapital, the fact remains that workplaces and work environments are undergoing major changes as remote work, home offices and other virtual options become more and more common. This study has shown how complex a form of employment home-based work is and how many different factors are involved. The reasons for its expansion are not simply the existence of a growing demand for flexible, lower-cost, time- and space-saving forms of labour or the development of information technologies that make it easier to monitor homebased work. Another factor - especially in relation to women - that must be considered has to do with patriarchal gender relations that limit women's ability to take part in the labour market on an equal footing with men.

This study's findings show that there are major gender-based differences in the factors underlying the decision to work from home, to work outside the home or to remain outside the workforce. In other words, it provides further evidence that the labour market is not gender-neutral, since there are informal cultural norms that result in gender segregation in certain sectors of the economy and certain types of employment, in addition to the vertical segregation discussed in the feminist economic literature.

The differentials between male and female heads of household stand out clearly, as was to be expected, and can be attributed to the presence of children, which increases the probability that women will work from 
home, either in the manufacturing sector or in the services industry, and decreases the probability that they will work outside the home. Another way of wording this is to say that home-based employment is functional in the presence of children and hinders women's participation in the non-home-based labour market. This points up the shortage of schools and childcare facilities that keep hours that would allow women to have a wider range of employment options. Furthermore, it had been expected that, with the increase in the female labourforce participation rate seen over the past two decades, marriage would cease to be an obstacle to women's employment; however, this study's findings regarding the negative correlation existing between marriage or involvement in a consensual union and employment in or outside the home suggest that this is still far from being the case. Single, separated or divorced women are the ones who are highly likely to be part of the workforce.

This confirms Kantor's (2000) assertion that homebased employment is a way for women to work and earn an income without challenging the patriarchal ideology of today's society. By contrast, these variables have no significant influence on men's decisions. Working from home gives women an opportunity to participate in the labour market under flexible conditions in terms of working hours and location, while enables them to combine their employment with domestic tasks. In men's case, there are other more important factors underlying their employment decisions. These findings confirm the conclusions reached by Rani and Unni (2009) and Edwards and Field-Hendrey (2002).

With regard to the gender-based segmentation of the spatial distribution of home-based work in the manufacturing sector, the high probabilities that such employment is concentrated in less urbanized and rural areas (only in the case of women) suggests, in addition, that a larger percentage of these female workers are engaged in the production of indigenous craftwork. This subject also calls for further research. It is noteworthy that the probability of being employed outside the home in highly urbanized areas was negative in 2010 for men, which indicates that the job crisis had a greater impact on men in urban areas.

The study also corroborates the finding that women's reservation wage for home-based work is quite low in both the manufacturing and services sectors and that the probability that they will engage in home-based employment is greater when they have not completed their secondary education. This is also true of men working in the manufacturing sector, but not in the services industry.
In the latter sector, the probability of male employment is high among men having professional and/or postgraduate degrees. It cannot be determined whether this is a reflection of the tendency of health professionals to work out of their homes, as they traditionally have done, or whether it is because there are more professionals who became unemployed and have started up businesses in their homes or because more professionals are taking advantage of new ways of working made possible by information technologies. This question raises another: Why do women professionals overwhelmingly tend to take part in the non-home-based workforce? This remains an open line of research.

Finally, if GDP growth can be taken as an acceptable indicator of economic conditions, then the results show that both men and women are more likely to engage in home-based employment in states with an average economic growth rate. One surprising result, however, was that women are more likely to participate in the labour market in any capacity in states where economic growth is low, whereas just the opposite is true of men. This may be attributable to the fact that women are in greater need of going out to work in order to supplement their households' incomes because job opportunities are lacking and/or because their husbands or children have migrated to the United States. On the other hand, the results for men suggest that economic growth spurs outsourcing and the demand for consultancies and that home-based work is a supplementary mechanism rather than a palliative measure for dealing with a tight job market.

The results obtained regarding non-home-based employment point up the difficulties faced by married women with children in working outside the home and underscore the fact that the public policy measures now in place have not succeeded in counteracting those difficulties.

The study indicates that the crisis had a stronger impact on the working population and particularly on home-based employment in the manufacturing sector, which fell off sharply. This may have been partially attributable to a shrinking demand for outsourced products such as furniture, clothing and metal products. This downturn was especially notable in the case of heads of household, many of whom moved into home-based employment in the services industry.

As for other factors that may help to account for decisions by male and female heads of household to work from home, the tendency for home-based employment participation rates to increase in older age groups suggests that the crisis-driven increase in unemployment drove many people into self-employment. 
The responsibilities associated with being in an intimate relationship continued to be an obstacle to employment. However, our findings indicate that they were less of an impediment in 2010, which indicates that the impact of the crisis on employment and on income levels prompted women to consider joining the workforce. The results also point up the difficulty that heads of household had in finding work in urban areas in 2010.

It is clear that home-based work has the advantage of serving as a means of earning an income. However, our results also show that wage levels for this form of employment are low. This corroborates the position taken by Atasü Topçuoglu (2005) and Hartmann (1979) regarding women's position within the labour market. These authors assert that the low level of women's wages obliges them to be dependent on their husbands, which means, in turn, that they are in charge of the housework. By the same token, their household duties weaken their position in the labour market, which translates into lower wages for them than for men. As also pointed out by Kabeer, Mahmud and Tasneem (2011), these wage levels are not necessarily high enough to empower women. One promising line for future research would be an examination of this issue in relation to home-based work in Mexico.

The findings of this study indicate that homebased work will continue to be an important form of employment for women and, increasingly, for men as well. Hence the need to explore possible legislative means of recognizing the rights of informal-sector workers and social policy options that would improve home-based working conditions by providing access to health care, social security coverage and training programmes. Thought could also be given to revamping social housing policies that have not taken the requirements of homebased employment into consideration. 
ANNEX

TABLE A.1

Results of the regressions: women

2005

No. of observations: 78279

Pseudo $\mathrm{R}^{2}$ 9.3\%, Prob. Wald 0.00

\begin{tabular}{|c|c|c|c|c|c|c|}
\hline & \multicolumn{2}{|c|}{ Home-based work } & \multirow{3}{*}{$\begin{array}{l}\text { Work outside } \\
\text { home }\end{array}$} & \multirow{2}{*}{\multicolumn{2}{|c|}{ Home-based work }} & \multirow{3}{*}{$\begin{array}{l}\text { Work outside } \\
\text { home }\end{array}$} \\
\hline & \multicolumn{2}{|c|}{ Home-based work } & & & & \\
\hline & Manufacturing & Services & & Manufacturing & Services & \\
\hline Primary & -0.013 & $-0.104 * *$ & $-0.170^{* * *}$ & -0.001 & 0.053 & $-0.174 * * *$ \\
\hline & $(0.055)$ & $(0.047)$ & $(0.020)$ & $(0.059)$ & $(0.050)$ & $(0.021)$ \\
\hline Upper-secondary & $-0.243 * *$ & 0.060 & $0.403 * * *$ & $-0.210 * * *$ & 0.021 & $0.384 * * *$ \\
\hline & $(0.114)$ & $(0.076)$ & $(0.030)$ & $(0.102)$ & $(0.078)$ & $(0.027)$ \\
\hline University and postgraduate & $-0.481 * * *$ & 0.063 & $0.947 * * *$ & $-0.471 * * *$ & $-0.123 * * *$ & $0.784 * * *$ \\
\hline & $(0.095)$ & $(0.060)$ & $(0.023)$ & $(0.096)$ & $(0.067)$ & $(0.023)$ \\
\hline Age & $0.138 * * *$ & $0.149^{* * *}$ & $0.184 * * *$ & $0.155^{* * *}$ & $0.158 * * *$ & $0.184 * * *$ \\
\hline & $(0.014)$ & $(0.012)$ & $(0.006)$ & $(0.015)$ & $(0.013)$ & $(0.006)$ \\
\hline $\mathrm{Age}^{2}$ & $-0.002 * * *$ & $-0.002 * * *$ & $-0.002 * * *$ & $-0.002 * * *$ & $-0.002 * * *$ & $-0.002 * * *$ \\
\hline & $(0.000)$ & $(0.000)$ & $(0.000)$ & $(0.000)$ & $(0.000)$ & $(0.000)$ \\
\hline Place of residence & $-0.706^{* * *}$ & $0.152 * * *$ & $0.162 * * *$ & $-0.639 * * *$ & $0.224 * *$ & $0.303 * * *$ \\
\hline & $(0.053)$ & $(0.042)$ & $(0.018)$ & $(0.055)$ & $(0.045)$ & $(0.017)$ \\
\hline Children aged 7 years or younger & -0.058 & $-0.072 * *$ & $-0.240 * * *$ & 0.074 & -0.067 & $-0.269 * * *$ \\
\hline & $(0.039)$ & $(0.031)$ & $(0.013)$ & $(0.071)$ & $(0.063)$ & $(0.022)$ \\
\hline Children aged 8 to 12 years & $0.120 * * *$ & 0.037 & $-0.024 * *$ & $0.215 * * *$ & $0.103 *$ & $0.022 * *$ \\
\hline & $(0.033)$ & $(0.028)$ & $(0.012)$ & $(0.058)$ & $(0.050)$ & $(0.019)$ \\
\hline Consensual union & $-0.532 * *$ & $-0.628 * * *$ & $-0.777 * * *$ & $-0.541 *$ & $-0.602 * * *$ & $-0.766 * * *$ \\
\hline & $(0.125)$ & $(0.105)$ & $(0.046)$ & $(0.136)$ & $(0.110)$ & $(0.046)$ \\
\hline Married & $-0.657 * * *$ & $-0.690 * * *$ & $-0.957 * * *$ & $-0.451 * * *$ & $-0.651 * * *$ & $-0.914 * * *$ \\
\hline & $(0.105)$ & $(0.088)$ & $(0.041)$ & $(0.115)$ & $(0.093)$ & $(0.041)$ \\
\hline Divorced & 0.468 & $0.502 * * *$ & $0.577 * * *$ & -0.022 & 0.181 & $0.364 * * *$ \\
\hline & $(0.202)$ & $(0.150)$ & $(0.071)$ & $(0.244)$ & $(0.163)$ & $(0.068)^{* * *}$ \\
\hline Separated & 0.473 & $0.665^{* * *}$ & $0.551 * * *$ & 0.402 & 0.317 & 0.452 \\
\hline & $(0.140)$ & $(0.110)$ & $(0.055)$ & $(0.153)$ & $(0.120)$ & $(0.054)$ \\
\hline Single & 0.433 & $0.570 * *$ & $0.702 * * *$ & 0.467 & 0.314 & $0.647 * * *$ \\
\hline & $(0.171)$ & $(0.130)$ & $(0.063)$ & $(0.169)$ & $(0.136)$ & $(0.059)$ \\
\hline & $(0.095)$ & $(0.060)$ & $(0.023)$ & $(0.096)$ & $(0.067)$ & $(0.023)$ \\
\hline Low-growth state & $0.193 * *$ & 0.028 & $0.096^{* * *}$ & $0.289 * * *$ & 0.134 & $0.138 * * *$ \\
\hline & $(0.080)$ & $(0.057)$ & $(0.022)$ & $(0.078)$ & $(0.059)$ & $(0.021)$ \\
\hline Average-growth state & $0.838 * * *$ & $0.521 * * *$ & $0.108 * * *$ & $0.847 * * *$ & $0.458 * * *$ & $0.099 * *$ \\
\hline & $(0.073)$ & $(0.052)$ & $(0.022)$ & $(0.073)$ & $(0.056)$ & $(0.021)$ \\
\hline Constant & -5.632 & -5.391 & -3.183 & -6.351 & -5.967 & -3.169 \\
\hline & $(0.331)$ & $(0.271)$ & $(0.127)$ & $(0.358)$ & $(0.304)$ & $(0.124)$ \\
\hline
\end{tabular}

Source: estimates computed on the basis of information from the National Occupation and Employment Survey and from the National Institute of Statistics and Geography (INEGI).

Note: $\mathrm{p}^{* * *}<0.01 ; \mathrm{p}^{* *}<0.05$
2010

No. of observations: 75950

Pseudo $\mathrm{R}^{2} 9.3 \%$, Prob. Wald 0.00 
Results of the regressions: men

\begin{tabular}{|c|c|c|c|c|c|c|}
\hline & \multicolumn{3}{|c|}{$\begin{array}{c}2005 \\
\text { No. of observations: } 64116 \\
\text { Pseudo R2 9.3\%, Prob. Wald } 0.00\end{array}$} & \multicolumn{3}{|c|}{$\begin{array}{c}2010 \\
\text { No. of observations: } 59342 \\
\text { Pseudo R2 9.3\%, Prob. Wald } 0.00\end{array}$} \\
\hline & \multicolumn{2}{|c|}{ Home-based work } & \multirow{2}{*}{$\begin{array}{l}\text { Work outside } \\
\text { home }\end{array}$} & \multicolumn{2}{|c|}{ Home-based work } & \multirow{2}{*}{$\begin{array}{l}\text { Work outside } \\
\text { home }\end{array}$} \\
\hline & Manufacturing & Services & & Manufacturing & Services & \\
\hline Upper-secondary & $\begin{array}{l}-0.358^{* *} \\
(0.123)\end{array}$ & $\begin{array}{c}0.002 * \\
(0.140)\end{array}$ & $\begin{array}{l}-0.169 * * * \\
(0.039)\end{array}$ & $\begin{array}{l}-0.121 * * \\
(0.135)\end{array}$ & $\begin{array}{c}0.187 * \\
(0.124)\end{array}$ & $\begin{array}{l}0.148 * * * \\
(0.050)\end{array}$ \\
\hline University and postgraduate & $\begin{array}{l}-1.174 * * * \\
(0.131)\end{array}$ & $\begin{array}{l}0.536^{* * * *} \\
(0.101)\end{array}$ & $\begin{array}{l}-0.399 * * * \\
(0.035)\end{array}$ & $\begin{array}{l}-1.145^{* * *} \\
(0.156)\end{array}$ & $\begin{array}{l}0.373 * * * \\
(0.100)\end{array}$ & $\begin{array}{l}0.104 * * * \\
(0.039)\end{array}$ \\
\hline Age & $\begin{array}{l}0.066^{* * * *} \\
(0.016)\end{array}$ & $\begin{array}{l}0.042 * * * \\
(0.018)\end{array}$ & $\begin{array}{l}0.030 \text { *** } \\
(0.007)\end{array}$ & $\begin{array}{l}0.113^{* * *} \\
(0.023)\end{array}$ & $\begin{array}{l}0.139 * * * \\
(0.02)\end{array}$ & $\begin{array}{l}0.065^{* * *} \\
(0.008)\end{array}$ \\
\hline $\mathrm{Age}^{2}$ & $\begin{array}{l}-0.001 * * * \\
(0.000)\end{array}$ & $\begin{array}{l}0.000 * * \\
(0.000)\end{array}$ & $\begin{array}{l}-0.001 * * * \\
(0.000)\end{array}$ & $\begin{array}{l}-0.002 * \\
(0.000)\end{array}$ & $\begin{array}{l}-0.002 * * * \\
(0.000)\end{array}$ & $\begin{array}{l}-0.001 * * * \\
(0.000)\end{array}$ \\
\hline Place of residence & $\begin{array}{c}0.036 \\
(0.071)\end{array}$ & $\begin{array}{l}0.403^{* *} \\
(0.087)\end{array}$ & $\begin{array}{l}0.324 * * * \\
(0.027)\end{array}$ & $\begin{array}{l}-0.328 \\
(0.0845)\end{array}$ & $\begin{array}{c}0.003 \\
(0.082)\end{array}$ & $\begin{array}{l}-0.253 * * * \\
(0.029)\end{array}$ \\
\hline Children aged 7 years or younger & $\begin{array}{l}-0.020 \\
(0.051)\end{array}$ & $\begin{array}{l}-0.056 \\
(0.065)\end{array}$ & $\begin{array}{l}-0.011 \\
(0.017)\end{array}$ & $\begin{array}{c}0.061 \\
(0.066)\end{array}$ & $\begin{array}{l}-0.092 \\
(0.063)\end{array}$ & $\begin{array}{l}-0.074 * * * \\
(0.027)\end{array}$ \\
\hline Children aged 8 to 12 years & $\begin{array}{c}0.007 \\
(0.046)\end{array}$ & $\begin{array}{c}0.052 \\
(0.052)\end{array}$ & $\begin{array}{l}-0.040 \\
(0.017)\end{array}$ & $\begin{array}{c}0.180 \\
(0.064)\end{array}$ & $\begin{array}{l}0.143 * * * \\
(0.060)\end{array}$ & $\begin{array}{l}0.143 * * * \\
(0.026)\end{array}$ \\
\hline Consensual union & $\begin{array}{c}0.013 \\
(0.276)\end{array}$ & $\begin{array}{c}0.390 \\
(0.306)\end{array}$ & $\begin{array}{l}-0.607 * * * \\
(0.137)\end{array}$ & $\begin{array}{c}0.402 \\
(0.356)\end{array}$ & $\begin{array}{c}0.283 \\
(0.272)\end{array}$ & $\begin{array}{c}0.073 \\
(0.081)\end{array}$ \\
\hline Married & $\begin{array}{c}0.000 \\
(0.258)\end{array}$ & $\begin{array}{c}0.209 \\
(0.288)\end{array}$ & $\begin{array}{l}-0.127 \\
(0.132)\end{array}$ & $\begin{array}{c}0.541 \\
(0.341)\end{array}$ & $\begin{array}{c}0.054 \\
(0.259)\end{array}$ & $\begin{array}{c}0.113 \\
(0.072)\end{array}$ \\
\hline Divorced & $\begin{array}{c}0.862 \\
(0.486)\end{array}$ & $\begin{array}{c}0.536 \\
(0.581)\end{array}$ & $\begin{array}{l}-0.670 * * * \\
(0.322)\end{array}$ & $\begin{array}{c}0.413 \\
(0.679)\end{array}$ & $\begin{array}{c}0.094 \\
(0.506)\end{array}$ & $\begin{array}{l}-0.266 \\
(0.182)\end{array}$ \\
\hline Single & $\begin{array}{c}0.111 \\
(0.565)\end{array}$ & $\begin{array}{l}-0.232 \\
(0.756)^{* * *}\end{array}$ & $\begin{array}{c}0.106 \\
(0.211)\end{array}$ & $\begin{array}{l}-0.268 \\
(1.072)\end{array}$ & $\begin{array}{l}-0.477 \\
(0.764)\end{array}$ & $\begin{array}{c}0.023 \\
(0.224)\end{array}$ \\
\hline Low-growth state & $\begin{array}{l}-0.113 \\
(0.090)\end{array}$ & $\begin{array}{l}-0.253 * \\
(0.094)\end{array}$ & $\begin{array}{l}-0.197 * * \\
(0.030)\end{array}$ & $\begin{array}{l}-0.096 \\
(0.110)\end{array}$ & $\begin{array}{l}-0.223 * * \\
(0.095)\end{array}$ & $\begin{array}{l}-0.038 \\
(0.035)\end{array}$ \\
\hline Average-growth state & $\begin{array}{c}0.018 \\
(0.087)\end{array}$ & $\begin{array}{l}-0.137 \\
(0.091)\end{array}$ & $\begin{array}{l}-0.369 * * * \\
(0.031)\end{array}$ & $\begin{array}{c}0.324 * \\
(0.106)\end{array}$ & $\begin{array}{c}0.165 \\
(0.091)\end{array}$ & $\begin{array}{l}0.155 * * * \\
(0.035)\end{array}$ \\
\hline Constant & $\begin{array}{l}-5.348 \\
(0.476)\end{array}$ & $\begin{array}{l}-5.926 \\
(0.546)\end{array}$ & $\begin{array}{l}-1.289 \\
(0.195)\end{array}$ & $\begin{array}{l}-4.053 \\
(0.651)\end{array}$ & $\begin{array}{l}-4.405 \\
(0.576)\end{array}$ & $\begin{array}{c}2.307 \\
(0.218)\end{array}$ \\
\hline
\end{tabular}

Source: estimates computed on the basis of information from the National Occupation and Employment Survey and from the National Institute of Statistics and Geography (INEGI).

Note: $\mathrm{p}^{* * *}<0.01 ; \mathrm{p}^{* *}<0.05 ; \mathrm{p}^{*}<0.10$.

\section{Bibliography}

Anderson, P.M. and P.B. Levine (1999), "Child care and mothers' employment decisions", JCPR Working Papers, No. 64, Chicago, Northwestern University/University of Chicago Joint Center for Poverty Research.

Aroche, F. and M.E. Cardero (2007), "Cambio estructural comandado por apertura comercial. El caso de la economía mexicana", Estudios Económicos, vol. 23, No. 2, Mexico City, Centro de Estudios Económicos, El Colegio de México.

Atasü Topçuoglu, R. (2005), "Home-based Work and Informal Sector in the Period of Globalisation: An Analysis Through Capitalism and Patriachy. The Case of Turkey", thesis, Ankara, The Graduate School of Social Sciences, Middle East Technical University.
Benería, L. (1981), "Gender and the dynamics of subcontracting in Mexico City", Gender in the Work Place, C. Brown and J.A. Pechman (eds.), Washington, D.C., The Brookings Institution. Benería, L. and M. Roldan (1992), Las encrucijadas de clase y género. Trabajo a domicilio, subcontratación y dinámica de la unidad doméstica en la Ciudad de México, Mexico City, El Colegio de México.

(1987), The Crossroads of Class and Gender: Industrial Homework, Subcontracting, and Household Dynamics in Mexico City, Chicago, The University of Chicago Press.

Benería, L. and others (2000), "Globalization and gender", Feminist Economics, vol. 6, No. 3, Taylor \& Francis. 
Bover, O. and M. Arellano (1995), "Female labour force participation in the 1980s: the case of Spain", Investigaciones Económicas, vol. 19, No. 2, Madrid, SEPI Foundation.

Çağatay, N. (2005), "Gender inequalities and international trade: a theoretical reconsideration", Seminarios y Talleres series, No. 136, Montevideo, Centro Interdisciplinary Centre for Development Studies.

Cardero, M.E. and G. Espinosa (2013), "Empleo, empleo informal de hombres y mujeres e indicadores de pobreza", México, mujeres y economía, Mexico City, Faculty of Economics, National Autonomous University of Mexico (UNAM).

Carr, M., A.M. Chen and J. Tate (2000), "Globalization and home-based workers", Feminist Economics, vol. 6, No. 3, Taylor \& Francis.

Cerda, M. (2011), "El 'home office' gana terreno en México", CNN Expansión [online] http://www.cnnexpansion.com/ opinion/2011/07/25/el-home-office-gana-terreno-en-mexico.

De Oliveira, O. and M. Eternod (2000), "La fuerza de trabajo en México: Un siglo de cambios", Cien años de demografía en México, J. Gómez de León and C. Rabell (eds.), Mexico City, Fondo de Cultura Económica.

Dedeoglu, S. (2010), "Visible hands - invisible women: garment production in Turkey", Feminist Economics, vol. 16, No. 4, Taylor \& Francis.

Edwards, L. and E. Field-Hendrey (2002), "Home-based work and women's labor force decisions", Journal of Labor Eoconomics, vol. 20, No. 1, Chicago, University of Chicago Press.

Elson, D. (1999), "Labor markets as gendered institutions: equality, efficiency and empowerment issues", World Development, vol. 27, No. 3, Amsterdam, Elsevier.

García, B. (2001), "Reestructuración económica y feminización del mercado de trabajo en México", Papeles de Población, vol. 7, No. 27, Toluca, Autonomous University of the State of Mexico.

García, B. and E. Pacheco (2000), "Esposa, hijos e hijas en el mercado de trabajo de la Ciudad de México en 1995", Estudios Demográficos y Urbanos, vol. 15, No. 1, Mexico City, Center for Demographic, Urban and Environmental Studies, El Colegio de México.

García, B. and O. De Oliveira (1994), Trabajo femenino y vida familiar en México, Mexico City, El Colegio de México.

Gereffi, G., J. Humphrey and T. Sturgeon (2005), "The governance of global value chains", Review of International Political Economy, vol. 12, No. 1, Taylor \& Francis.

Hartmann, H. (1979), "The unhappy marriage of Marxism and feminism: towards a more progressive union”, Capital and Class, vol. 3, No. 2, Sage.

Huber, P.J. (1967), "The behavior of maximum likelihood estimates under nonstandard conditions", Proceedings of the Fifth Berkeley Symposium on Mathematical Statistics and Probability, Berkeley, University of California Press.

ILO (International Labour Office) (2005), "Economía informal en las Américas: Situación actual, prioridades de políticas y buenas prácticas", "Principios y derechos en el trabajo en el contexto de la XIII Conferencia Interamericana de Ministros de Trabajo de la OEA" project, Lima.

Juárez, H. (2004), Allá donde viven los más pobres. Cadenas globales y regiones productoras en la industria del vestido, Mexico City, Universidad Obrera de México.
Kabeer, N., S. Mahmud and S. Tasneem (2011), "Does paid work provide a pathway to women's empowerment? Empirical findings from Bangladesh", IDS Working Paper, vol. 2011, No. 375, Brighton, Institute of Development Studies.

Kantor, P. (2003), "Women's empowerment through home-based work: evidence from India", Development and Change, vol. 34, No. 3, Wiley.

(2000), Gender Differentials in Microenterprise Success for Homebased Garment Makers in Ahmedabad, Chapel Hill, University of North Carolina.

Knaul, F. and S.W. Parker (1997), "Estrategias de empleo y cuidado de los niños entre mujeres mexicanas con hijos pequeños", paper presented at the II Seminario de investigación laboral: Participación de la mujer en el mercado laboral, Mexico City, Secretariat of Labour and Social Security.

Langlois, R. (1995), "The vanishing hand: the changing dynamics of industrial capitalism", Industrial and Corporate Change, vol. 12, No. 2, Oxford, Oxford University Press.

López, E.S. (2005), "Trabajo a domicilio, pequeños talleres y precariedad laboral en Piedra Negras y Torreón”, Mexico City, Instituto de Estudios del Trabajo.

Louw, E. and P. De Vries (2002), "Working at home: the Dutch property dimension”, Planning Practice and Research, vol. 17, No. 1, Taylor \& Francis.

Maldonado, V. and T. Rendón (2004), "Vínculos entre trabajo doméstico, segregación ocupacional y diferencias de ingreso por sexo en el México actual", Mexico City, Instituto de Estudios del Trabajo.

Marx, Karl (1967), Capital, Mexico City, Fondo de Cultura Económica.

Millán, León Beatriz (2010), "Factores asociados a la participación laboral de los adultos mayores mexiquenses", Papeles de Población, vol. 16, No. 64, Toluca, Autonomous University of the State of Mexico.

Ocampo, J.A. and J. Ros (2011), "Raul Prebisch y la agenda del desarrollo en los albores del siglo XXI", paper presented at the Seminar "La teoría del desarrollo en los albores del siglo XXI", Santiago, Chile, Economic Commission for Latin America and the Caribbean (ECLAC).

Pearson, R. (2004), "Towards the re-politicization of feminist analysis of the global economy", International Feminist Journal of Politics, vol. 6, No. 4, Taylor \& Francis.

Piore, M.J. and C.F. Sabel (1984), The Second Industrial Divide, New York, Basic Books.

Rani Uma and Jeemol Unni (2009), "Do economic reforms influence home-based work? Evidence from India", Feminist Economics, vol. 15, No. 3, Taylor \& Francis.

Rendón, G.T. and C. Salas (2000), Segregación y diferencias salariales por género. Hipótesis y evaluación empírica, Mexico City, Secretariat of Labour and Social Security.

Thompson, E.P. (1963), The Making of the English Working Class, London, V. Gollancz.

Tokman, V.E. (2008), "Flexiguridad con informalidad: Opciones y restricciones", Macroeconomía del Desarrollo series, No. 70 (LC/L.2973-P), Santiago, Chile, Economic Commission for Latin America and the Caribbean (ECLAC). United Nations publication, Sales No. S.08.II.G.83.

White, H. (1982), "Maximum likelihood estimation of misspecified models", Econometrica, vol. 50, No. 1, New York, The Econometric Society. 